\title{
Economics of Aus Rice (Oryza sativa) and Jute (Corchorus olitorius) Cultivation in Some Selected Areas of Narsingdi District of Bangladesh
}

\author{
Sadia Afroz ${ }^{*}$ and M. Serajul Islam \\ Dept. of Agricultural Economics, Bangladesh Agricultural University, Mymensingh- 2202, Bangladesh \\ *Corresponding author and Email: afrozbau88@gmail.com
}

Received: 15 May $2012 \quad$ Accepted: 15 November 2012

\begin{abstract}
The present study was conducted to estimate the relative profitability of growing aus rice and jute and to determine the resource use efficiency in the production of these crops in three selected village of Raipura upazila in Narsingdi. A total of 60 farmers were interviewed to collect primary data of which 30 farmers were produced aus rice and another 30 farmers were produced jute. Total costs for producing jute and aus rice were Tk 50254 and 44970 per hectare, respectively. The equivalent gross returns were Tk 83717 and Tk 55762, respectively. Accordingly, net return for jute was Tk 33463, which was about 3 times higher than that for aus rice (Tk. 10792/hectare). Moreover, BCR of producing jute was about $30 \%$ higher (1.7) than that of aus rice (1.3). Cobb-Douglas production function was used to estimate specific effects of individual inputs on production of jute and aus rice. Resource use efficiency analysis showed that neither jute nor aus rice farmers was efficient enough to use various inputs. Therefore, it seems that efficient and judicious use of various resources would enable both jute and aus rice farmers to earn more profit.
\end{abstract}

\section{Keywords: Rice and jute cultivation, profitability, resource use efficiency}

\section{Introduction}

Bangladesh economy is dominated by agriculture. Agriculture contributes about 19.95 percent to the Gross Domestic Product (GDP) of which 11.24 percent comes from crops (GOB, 2011). Agriculture sector continues to play a very important role in the economy of Bangladesh. Aus rice and jute are important crops in Bangladesh. There are three seasons in Bangladesh namely Aus, Aman and Boro. Among the three rice seasons Aus rice covers about $12.27 \%$ of the rice growing area. The country's total aus rice production is 1895 thousand tones (BBS, 2009). In Asia alone, more than 2 billion people obtain 60 to 70 percent of their calorie intake from rice products (FAO,
2003). It is the main source of carbohydrate of almost 40 percent of the world population (Hoffman, 1991). Among the rice producing countries, Bangladesh possesses fourth position in the world after China, India and Indonesia (FAO Rice Market Monitor, 2010). Again Bangladesh is the second major jute producing countries of the world. It plays an important role in the field of agriculture. Aus rice and jute are grown in the same season known as Kharif-1 (mid March to June). As an alternate cropping pattern, rice and jute production areas are expanding in Bangladesh. The government of Bangladesh has been pursuing a crop diversification strategy to reduce the dependency on rice. During 1960-70s, introduction of artificial fibre reduced the demand for jute. 
Recently, awareness of environmental degradation due to use of artificial fibre has generated tremendous interest among the international community. The government of Bangladesh has banned production, sale and use of polythene since 01 March 2002. As a result, the demand for jute and jute products is increasing in domestic market. Farmers have starting to grow jute again.

Although, there are some studies conducted on the economics of jute and rice, a little research was conducted on rice as an alternate crop of jute. Morsalina (2010) conducted a comparative economic analysis of White and Tossa jute production in a selected area of Sirajganj district. She found that per hectare net return for White jute was Tk 18,988 and that of Tossa jute was Tk 38,832 which was much higher compared to White jute. Yasmin (2009) studied the supply response growth of jute in Bangladesh and found that growth rate of area and production of jute had declined significantly at the rate of 2.26 and 0.95 percent, respectively over the period from 1980-1981 to 2005-2006. Partway (2000) examined the regional production performance and the factors influencing area and production of four food grain crops- Aus rice, Aman rice, Boro rice and Wheat. He found that during 197677 to $1997-98$ area, yield and production of food grains exhibited considerable differences amoung the regions. Talukdar et al. (1993) conducted a study on relative profitability of Aus paddy and Jute production in selected areas of Tangail district and showed that Tossa jute offered more gross margin compared to both Aus and White jute. However, the present study was conducted to compare the profitability of jute and aus rice production and to determine the factors affecting economic returns and resource use efficiency of producing jute and aus rice in some selected areas of Bangladesh.

Cropping pattern as well as farming systems have been changed by the farmers with the introduction of new technologies and better management practices. Under this farming situation farmers also have changed their land use pattern and introduced new enterprises combination along with rice production (Islam et al., 2010). As a result, aus rice land has been shifted and to jute production. Since jute and aus rice are two competitive crops of the Kharip-I season, the farmers are likely to redistribute their land between aus rice and jute for more economic gains. Table 1 show that farmers cultivated more jute because of its high demand and fair prices both in the national and international market.

Table 1. Trend of changing land allocation between jute and aus rice production

\begin{tabular}{ccc}
\hline Year & $\begin{array}{r}\text { Area under jute production } \\
\text { ('000' acres) }\end{array}$ & $\begin{array}{c}\text { Area under Aus rice } \\
\text { production ('000’ acres) }\end{array}$ \\
\hline $2000-01$ & 1107 & 3275 \\
$2001-02$ & 1128 & 3069 \\
$2002-03$ & 1079 & 3073 \\
$2003-04$ & 1008 & 2971 \\
$2004-05$ & 965 & 2532 \\
$2005-06$ & 993 & 2556 \\
$2006-07$ & 1034 & 2238 \\
$2007-08$ & 1089 & 2270 \\
\hline
\end{tabular}

Source: BBS, 2009 


\section{Methodology and Analytical Techniques Used}

Data were collected during August to September, 2011 from selected farmers of three villages under Raipura Upzilla of Narsingdi district. Primary data were collected from 60 farmers, of which 30 farmers from each of aus rice and jute cultivators in the same season were selected randomly. Data were collected using prescheduled questionnaire. Both descriptive and statistical methods were used to analyses the data. The descriptive statistics is a technique that is commonly used for the sum, average, percentage of costs, gross returns, net returns and profitability of jute and aus rice farmers. In this study, cost factors consisted of human labour, seed/seedlings, power tiller, fertilizers, manure, insecticide and irrigation.

The Cobb-Douglas (C-D) production function was used to estimate the major factors affecting gross returns for jute and aus rice production. However, the following C-D production function was used:

$$
Y=a X_{1}^{b 1} X_{2}^{b 2} X_{3}^{b 3} X_{4}^{b 4} X_{5}^{b 5} X_{6}^{b 6} X_{7}^{b 7} X_{8}^{b 8} e^{u i}
$$

The function was transformed into the following double $\log$ or $\log$ linear form

$\ln \mathrm{Y}=\ln \mathrm{a}+\mathrm{b}_{1} \ln \mathrm{X}_{1}+\mathrm{b}_{2} \ln \mathrm{X}_{2}+\mathrm{b}_{3} \ln \mathrm{X}_{3}+\mathrm{b}_{4} \ln$ $X_{4}+b_{5} \ln X_{5}+b_{6} \ln X_{6}+b_{7} \ln X_{7}+b_{8} \ln X_{8}+u i$

Where,

$\mathrm{Y}=$ Gross return $(\mathrm{Tk} / \mathrm{ha})$

$\mathrm{X} 1=$ Farm size (ha)

$\mathrm{X}_{2}=$ Human Labor $(\mathrm{Tk} / \mathrm{ha})$

$\mathrm{X}_{3}=$ Seed/seedlings cost $(\mathrm{Tk} / \mathrm{ha})$

$\mathrm{X}_{4}=$ Fertilizer cost $(\mathrm{Tk} / \mathrm{ha})$

$\mathrm{X} 5=$ Cost of manure $(\mathrm{Tk} / \mathrm{ha})$

$\mathrm{X}_{6}=$ Insecticide cost $(\mathrm{Tk} / \mathrm{ha})$

$\mathrm{X}_{7}=$ Power tiller cost $(\mathrm{Tk} / \mathrm{h})$

$\mathrm{X}_{8}=$ Irrigation cost $(\mathrm{Tk} / \mathrm{ha})$

$\mathrm{a}=$ Intercept

$b_{1}, b_{2}, b_{3}, b_{4}, b_{5}, b_{6}, b_{7}, b_{8}=$ Production coefficient of the respective variable inputs

$\mathrm{U}_{\mathrm{i}}=$ Disturbance term

Allocation efficiency was tested by applying Equi-marginal principle. Allocation efficiency of the factor inputs was defined as the ratio of marginal value product (MVPs) to the marginal factor costs $\left(\mathrm{MFC}_{\mathrm{S}}\right)$ of each variable input. When MVPs is equal to $\mathrm{MFC}_{\mathrm{S}}$ then the profit is maximized. If it is greater than one, the resource is sub-optimally used and if it is less than one, the resource is over used. Resource use efficiency of an input is calculated by using the basic economics formula as MVP/MFC $=1$.

According to Dhawan and Bansal (1977), the useful estimate of MVP is obtained by taking the geometric mean of the resources $\left(\mathrm{x}_{\mathrm{i}}\right)$ as well as the gross return. MVP is calculated by multiplying the coefficient of a given resource with the ratio of the geometric mean of the resource i.e

$d Y / d X_{i}=b_{i} \cdot Y / X_{i}$ thus MVP $\left(x_{i}\right)=b_{i} . Y_{i} / X_{i}$

Where,

$\mathrm{dY} / \mathrm{dX}_{\mathrm{i}}=$ slope of the production function

$\mathrm{b}_{\mathrm{i}}=$ Regression co-efficient

$\mathrm{X}_{\mathrm{i}=}$ Mean value $(\mathrm{GM})$ of gross return in $\mathrm{Tk}$

$\mathrm{Y}_{\mathrm{i}}=$ Mean value $(\mathrm{GM})$ of different resources in $\mathrm{Tk}$

$\mathrm{i}=(1,2,3$. ..n)

$\mathrm{GM}=$ Geometric mean

\section{Results and Discussion}

This section discusses the cost and returns of jute and aus rice production, factor affecting jute and aus rice production and resource use efficiency in aus rice and jute production.

\subsection{Costs and returns of aus rice and jute production}

Aus rice and jute production requires a large number of inputs like human labour, seed/seedlings, fertilizer, manure, insecticide, power tiller and irrigation. Table 2 shows cost of aus rice and jute production. Production cost per hectare was higher for jute than for aus rice. Per hectare cash costs were Tk 32508 and 31190 for jute and aus rice cultivation and their corresponding non-cash costs were Tk 17745 and 13780 and those of total cost were Tk 50254 and 44970, respectively. 
Table 2. Per hectare costs of jute and aus rice production

\begin{tabular}{lcc}
\hline Items & Jute cost (Tk) & Aus rice cost (Tk) \\
\hline i. Cash cost & 18720 & 17340 \\
Hired labour & 1488.6 & 2000 \\
Seeds/seedlings & 6645.87 & 3949.93 \\
Power tiller & & \\
Fertilizer & 2085.36 & 2480 \\
Urea & 1798.33 & 1474 \\
TSP & 1067.22 & 1059.97 \\
MP & - & 218.51 \\
Gypsum & - & 653.13 \\
Zinc & 703.27 & 1328.87 \\
Insecticides & - & 750 \\
Irrigation & 32508.65 & 31190.64 \\
Total cash cost & & 6000 \\
ii. Non-cash cost & 17745.54 & 6089 \\
Family labour & 50254.19 & 911 \\
Home supplied cowdung & 10080 & 780 \\
Interest on operating capital & 852.54 & \\
Land used cost & 813 & \\
Total non-cash cost & 6000 & \\
\hline Total cost (i + ii) & & \\
\hline
\end{tabular}

Gross returns are the monetary value of produced crop and it was calculated by multiplying the total produced aus rice and jute by their respective market price. Table 3 shows various returns from aus rice and jute production. It is evident from the table that per hectare gross returns of jute was also higher than that of aus rice. Per hectare gross returns were Tk 83717 and 55762 for jute and aus rice farmers and their corresponding net returns were $\mathrm{Tk} 33463$ and
10792, respectively. Again, return over cash cost for jute and aus rice were Tk 51209 and 24572, respectively and those of return over non-cash costs for jute and aus rice were Tk 65972 and 41982, respectively. Undiscounted benefit cost ratio on total cost basis was higher for jute (1.7) than that of aus rice (1.3). Moreover, it is clear that jute production was more profitable compared to aus rice production in the study area. 
Table 3. Comparative costs and returns of jute and aus rice production

\begin{tabular}{lcc}
\hline Particulars & Jute & Aus rice \\
\hline Gross return & 83717.77 & 55762.79 \\
Total cost & 50254.19 & 44970.72 \\
Non cash cost & 17745.54 & 13780.1 \\
Cash cost & 32508.65 & 31190.64 \\
Net return & 33463.58 & 10792.07 \\
Return over cash cost (Tk) & 51209.12 & 24572.15 \\
Return over non cash cost (Tk) & 65972.23 & 41982.69 \\
BCR (Undiscounted) & 1.7 & 1.3 \\
\hline
\end{tabular}

\subsection{Factors affecting aus rice and jute production}

The contribution of specified factors affecting production of aus rice and jute is shown in Table 4. In the present study, two forms of production function model were initially estimated to determine the effects of various inputs. They were linear and Cobb-Douglas forms. Finally, Cobb-Douglas production function was chosen on the basis of best fit and significant result on output. The explanatory variables were farm size, human labour, seed, power tiller, fertilizer, insecticides for jute production and farm size, human labour, seedlings, power tiller, fertilizer, insecticides and irrigation for aus rice production. Estimated values of the relevant coefficients revealed that among the included variables, seeds, fertilizer, manure and insecticide had positive and significant effect on jute cultivation. However, farm size, human labor and power tiller showed insignificant effect on gross return.

In case of aus rice production, manure and seedlings cost co-efficient showed positive and significant effect, power tiller showed negative but significant effect. Farm size, human labor, fertilizer and insecticides showed insignificant effect on gross return of aus rice. It was found that coefficient of multiple determinations $\left(\mathrm{R}^{2}\right)$ for jute and aus rice were 0.78 and 0.61 , respectively indicating that 78 percent and 61 percent of total variation of jute and aus rice production could be explained by the explanatory variables included in the model. The measures of the overall significance of the estimated regression $F$ values were 5.11 and 3.6 for jute and aus rice, they were significant at 1 percent probability level implying that all the explanatory variables, included in the model, were important for explaining the variation of jute and aus rice production. Summation of coefficient of all inputs for jute and aus rice was found to be 0.44 and 0.59 , respectively. This implies that the production function exhibits decreasing returns to scale both for jute and aus rice. That is, the farmers were operating their jute and aus rice farming in the second stage of production function. That means there is no need to increase allocating more resources for higher jute and aus rice production, because it is known that second stage of production does not give the same output as input given. In this case, if all the variables specified in the production function were increased by 1 percent, gross returns would increase by 0.44 and 0.59 percent for jute and aus rice, respectively. 
Table 4. Estimated values of coefficient and related statistics of Cobb-Douglas production function model for jute and aus rice production

\begin{tabular}{lcc}
\hline Explanatory variable & Jute & Aus rice \\
\hline Intercept & 12.47 & 10.49 \\
Farm size $\left(\mathrm{X}_{1}\right)$ & -0.035 & -0.156 \\
& $(0.042)$ & $(0.161)$ \\
Human labor cost $\left(\mathrm{X}_{2}\right)$ & 0.156 & 0.148 \\
& $(0.095)$ & $(0.251)$ \\
Seed/seedlings cost $\left(\mathrm{X}_{3}\right)$ & $0.204^{* * *}$ & $0.534^{* *}$ \\
& $(0.106)$ & $(0.274)$ \\
Fertilizer cost $\left(\mathrm{X}_{4}\right)$ & $0.146^{*}$ & 0.193 \\
& $(0.088)$ & $(.272)$ \\
Manure cost $\left(\mathrm{X}_{5}\right)$ & $0.017^{* * *}$ & $0.052^{* * *}$ \\
& $(0.009)$ & $(0.014)$ \\
Insecticide cost $\left(\mathrm{X}_{6}\right)$ & $0.019^{*}$ & 0.019 \\
& $(0.011)$ & $(0.139)$ \\
Power tiller cost $\left(\mathrm{X}_{7}\right)$ & -0.070 & $-0.15^{* * *}$ \\
& $(0.064)$ & $(0.698)$ \\
Irrigation cost $\left(\mathrm{X}_{8}\right)$ & & -0.05 \\
$\mathrm{R}^{2}$ & - & $(0.139)$ \\
Adjusted $\mathrm{R}^{2}$ & 0.78 & 0.61 \\
$\mathrm{~F}-$-value & 0.74 & 0.58 \\
Returns to Scale $\left(\sum \mathrm{b}_{\mathrm{i}}\right)$ & 5.11 & 3.6 \\
\hline
\end{tabular}

*** Significant at 1 percent level

** Significant at 5 percent level

* Significant at 10 percent level

Note: Figures in the parentheses indicate slandered error

\subsection{Resource use efficiency}

The resource is considered to be efficiently used as well as profit will be maximized when the ratio of MVP to factor MFC approaches one, in other words MVP and MFC for each input are equal. If it is greater than one, the resource is sub-optimally used and the gross return could be increased by using more of the resource and if it is less than one, the resource is over used and the excess use of resource should be decreased to minimize the loss. Table 5 shows that none of the Marginal Value Products of inputs were equal to one. In case of aus rice, the obtained ratios were $0.34,9.68,18.67,1.51,0.48,-1.57$ and -3.51 , respectively. The MVP of human labor and insecticide were less than 1 and positive, which indicate that farmers should limit the use of these inputs to increase the return. The MVP of seedlings, fertilizer and manure were $9.68,18.67$ and 1.51 , indicating that there was more scope for use of these inputs to increase the 
Table 5. Ratio of marginal value products (MVPs) and marginal factor costs $\left(\mathrm{MFC}_{\mathrm{S}}\right)$ of different inputs incurred in producing aus rice and jute

\begin{tabular}{lcccccc}
\hline \multirow{2}{*}{ Inputs } & \multicolumn{3}{c}{ Aus rice } \\
\cline { 2 - 6 } & $\begin{array}{c}\text { Geometric } \\
\text { mean }\end{array}$ & $\begin{array}{c}\text { Co- } \\
\text { efficient }\end{array}$ & $\begin{array}{c}\text { The ratio of } \\
\mathrm{MVP}_{\mathrm{Xi}} \text { and } \\
\mathrm{MFC}_{\mathrm{Xi}}\end{array}$ & $\begin{array}{c}\text { Geometric } \\
\text { mean }\end{array}$ & $\begin{array}{c}\text { Co- } \\
\text { efficient }\end{array}$ & $\begin{array}{c}\text { The ratio of } \\
\mathrm{MVP}_{\mathrm{Xi}} \text { and } \\
\mathrm{MFC}_{\mathrm{Xi}}\end{array}$ \\
\hline Return & 51534.15 & & & 84120 & & \\
Human labor & 22584.07 & 0.148 & 0.34 & 23017.27 & 0.156 & 0.57 \\
Seedlings & 2841.82 & 0.534 & 9.68 & 1486.83 & 0.204 & 11.54 \\
Fertilizer & 6603.14 & 0.193 & 18.68 & 4783.85 & 0.146 & 6.21 \\
Manure & 143.55 & 0.052 & 1.51 & 230.14 & 0.017 & 2.57 \\
Insecticide & 2020.70 & 0.019 & 0.48 & 170.17 & 0.019 & 9.39 \\
Power tiller & 4926.09 & -0.15 & -1.57 & 6382.40 & -0.07 & -0.92 \\
Irrigation & 735.1 & -0.05 & -3.51 & & & \\
\hline
\end{tabular}

return. The MVP of power tiller and irrigation were -1.57 and -3.51 , which indicate that farmers might have made less use of these inputs (Table $4)$. In case of jute, the obtained ratios were 0.37 , $11.54,6.21,2.57,9.39$ and -0.92 , respectively. All these ratios are different from one, which indicate inefficient use of the resources. The MVP of human labor was less than one but positive, which means that farmers should limit the use of these inputs. The MVP of seed, fertilizer, manure and insecticide were 11.54, 2.57, 6.21 and 9.39, indicating that there was more scope for use of these inputs to increase the return. The MVP of power tiller was less than 1 and negative, which indicate that farmers might have made excessive use of these inputs.

\section{Conclusions}

The study show that jute production is highly profitable compared to aus rice and it helped improve the socioeconomic conditions of jute farmers in the study areas. Furthermore, both jute and aus rice production are labour intensive; it would help creating employment opportunities. Among the selected eight independent variables, seeds/seedlings, fertilizer, manure and insecticide have significant and positive effect on jute and aus rice production. The management practices of jute and aus rice enterprises in the study areas were not found efficient enough. Farmers did not know about the application of inputs in time in right doses. Consequently, they could not use some inputs optimally. Thus, if better culture and management could be introduced, then both production and income of these two crops would be increased to some extent.

\section{References}

BBS 2009. Statistical Yearbook of Bangladesh, Statistics Division, Ministry of Planning, Government of the People's Republic of Bangladesh, Dhaka.

Dhawan, K. G. and Bansal, P. K. 1977. Rationality of the use of various factors of production on different of farming in Panjab, Indian Journal of Agricultural Economics, 32 (3):121-130.

FAO 2010. Rice Market Monitor, Food and Agriculture Organization, Rome, Italy, Volume XIII-Issue No. 3.

FAO 2003. Production Yearbook, Food and Agriculture Organization, Rome, Italy, Vol. 56.

GOB 2011. "Bangladesh Economic Review", Economic Division, Ministry of Finance, 
Government of the People's Republic of Bangladesh, Dhaka, 22 p.

Hoffman, M. S. 1991. The world Almanac Book Facts. An important of phares books. A Secips Howard Company, 200 Park, Avenue, New York.

Islam, M. S., Miah, T. H., Rahman, K. M. M and Haque, M. M. 2010. Land use patterns and food security of farm households in Bangladesh. National Food Policy Capacity Strengthening Programme (NFPCSP), FAO. Food and Agricultural Organization of the United Nations, Rome, Italy, 26-30 \& 56-58 pp.

Khatun, M. 2010. A comparative economic analysis of white and tossa jute production in a selected area of Sirajganj district, M.S. Thesis, Department of Agril.
Economics, Bangladesh Agricultural University, Mymensingh 2202.

Patwary, M. W. R. 2000. A study of regional variation in the production performance of foodgrains in Bangladesh, M.S. Thesis, Department of Agricultural Economics, Bangladesh Agricultural University, Mymensingh 2202.

Talukdar, F. A. H., Hossain, M. A. and Molla, A. R. 1993; Relative profitability to Aus paddy and jute production in selected areas of Tangail district in Bangladesh, Bangladesh Journal of Agricultural Economics, 15(1): 95-102.

Yasmin, S. 2009; A supply response and growth study of jute in Bangladesh, M.S. Thesis, Department of Agribusiness and Marketing, Bangladesh Agricultural University, Mymensingh 2202. 